\title{
AMMONIUM OXALATE AND CITRATE-ASCORBATE AS SELECTIVE CHEMICAL AGENTS FOR THE MINERALOGICAL ANALYSIS OF CLAY FRACTIONS OF AN ULTISOL AND ANDISOLS FROM SOUTHERN CHILE
}

\author{
C. PIZARRO', J.D. FABRIS', J.W.STUCKI', V.K. GARG ${ }^{4}$, AND G. GALINDO
}

${ }^{1}$ Facultad de Química y Biología, USACH, Av. L. B. O’Higgins 3363, Santiago, 7254758, Chile (cpizarro@lauca.usach.cl); ${ }^{2}$ Departamento de Química - ICEx, UFMG, Pampulha, 31270-901 Belo Horizonte, MG, Brazil; ${ }^{3}$ Department of Natural Resources and Environmental Sciences, University of Illinois, Urbana, IL 61801, USA; and ${ }^{4}$ Instituto de Física, Universidade de Brasília, 70919-970 Brasilia, DF, Brazil

(Received: September 3, 2007 - Accepted: March 26, 2008)

\begin{abstract}
Two selective chemical treatments consisting of mixtures of (i) oxalic acid - ammonium oxalate at $\mathrm{pH} 3(\mathrm{OX})$ and (ii) sodium citrate - ascorbic acid at pH 6 (CA) were used to selectively remove minerals from clay fractions of four volcanic soils: one from an Ultisol and three Andisols, of the southern Chile. Chemical analysis shows that CA is more effective in removing iron from Ultisol, and OX extracts it more efficiently from Andisols. $6 \mathrm{~K}{ }^{57} \mathrm{Fe}-\mathrm{Mössbauer}$ data indicate that OX tends to remove all magnetically ordered species with low hyperfine fields; CA has no clear effect on the removal of those or the identified iron oxides in these volcanic soil materials.
\end{abstract}

\section{INTRODUCTION}

Selective chemical dissolution treatments are useful, and in many circumstances essential, laboratory procedures in order to improve the mineralogical analysis of soil samples. However, no chemical extractive solution, whatever the chemical dissolution mechanism, is expected to completely dissolve certain groups of chemically related minerals, while leaving unaffected the other species. In soils, iron (oxyhydr)oxides very often occur as a continuum of inter-related mineral forms or assemblages of strongly cemented multiphase grains in heterogeneous systems, of a wide range of degree of crystallinity.

Cornell and Schwertmann ${ }^{1}$ reviewed the currently used methods for differential dissolution to concentrate and/or to selectively dissolve minerals. Such procedures in soil research are, however, still largely empirical. The following are the most conventional laboratory procedures. Sodium hydroxide is used to preferentially remove silicate and gibbsite ${ }^{2,3}$. Acid - ammonium oxalate $(\mathrm{OX})$ is an effective and simple extraction method that has been widely used to dissolve magnetite ${ }^{4}$, dioctahedral layer silicates ${ }^{5}$, allophane, and, if the reaction is carried out in darkness, poorly crystallized ${ }^{6,7,8}$ or 'active' iron oxides $^{9}$ in soils; citrate-bicarbonate-dithionite (CBD) also removes crystalline iron oxides ${ }^{10}$ and preferentially attacks pedogenic maghemite over lithogenic magnetite ${ }^{11}$.

Only a relatively limited number of works dedicated to the mineralogy of volcanic Chilean soils (mainly, Andisols and Ultisols) have been actually reported, despite their abundant and widespread occurrence in southern Chile and their actual and potential importance for agricultural practices. An important overview of volcanic soils in Chile was given by Besoaín ${ }^{12}$.

Regarding chemical methods for mineralogical analysis of volcanic Andisols and Ultisols, available reported data have been mainly focused on their pedological characterization, through the application of specific selective treatments ${ }^{13,14}$. OX and CBD treatments were first used to extract "active" forms of aluminum and iron, and results were taken as a criterion to characterize Andisols. More recent data in the scientific literature are specifically dedicated to the application of chemically selective treatments as ancillary methods for mineralogical studies of volcanic Chilean pedo-materials ${ }^{15,16,17,18}$, particularly of the two dominant soil orders, namely, Andisol and Ultisol.
The OX and CBD solutions were proposed and are conventionally used to remove "active" forms containing aluminum or iron from materials of pedosystems regardless of their origins. Reyes and Torrent ${ }^{19}$ found that an extractive solution of sodium citrate - ascorbic acid, at $\mathrm{pH} 6$, generally can be used for the selective extraction of poorly crystalline iron oxides, even though ascorbate is a relatively weak reducing and complexing agent.

More recently, Pizarro et al. ${ }^{20}$ used OX treatments to specifically improve the Mössbauer spectra mineralogical analysis of volcanic materials. Those results, along with powder X-ray diffraction (XRD) data ${ }^{21}$ for the clay fractions, indicated that Andisols are characterized by high contents of poorly organized aluminosilicates and iron oxides. On the other hand, Ultisols, which are pedogenetically more developed than Andisols, have a mineralogy that is more typically characterized by crystalline compounds and higher iron oxides contents.

In the present work, two chemical treatments, namely (i) oxalic acid ammonium oxalate at $\mathrm{pH} 3(\mathrm{OX})$ and (ii) a mixture of sodium citrate - ascorbic acid at $\mathrm{pH} 6(\mathrm{CA})$, were used as an attempt to verify their effectiveness in the selective dissolution of poorly crystalline iron oxides from clay fractions obtained from an Ultisol and three Andisols of southern Chile. The effects were monitored with Mössbauer spectroscopy and scanning electron microscopy (SEM) of the residual fractions and by chemical analysis of solutions after treatments, in order to help elucidate the chemical action on their main minerals, particularly on the dissolution of less-crystalline iron oxides.

\section{MATERIAL AND METHODS}

Soil profiles from land areas that were kept uncultivated for at least the last 30 years were sampled in four locations in southern Chile, as follows: (i) Ultisol from Collipulli (Soil Orders according to the United States Soil Taxonomy system ${ }^{22}$ ), (ii) Andisol from Diguillín, (iii) Andisol from Ralún, and (iv) Andisol from Freire. Identification, classification, and general pedological data for these soils are given in Table 1. The samples were collected from 20$40 \mathrm{~cm}$ depth for Collipulli, Diguillín, and Freire and 7-20 cm depth for Ralún. They were sieved with a $2-\mathrm{mm}$ sieve and stored at their characteristic field capacity, a measure of the maximum amount of water retained by the soil23. The particle size fractionation was carried out by dispersing about $30 \mathrm{~g}$ of each soil sample in distilled water and removing the clay fraction $(\phi<2 \mu \mathrm{m})$ by sedimentation, according to the method of Jackson ${ }^{24,25}$.

Table 1. Main characteristics of the soil samples.

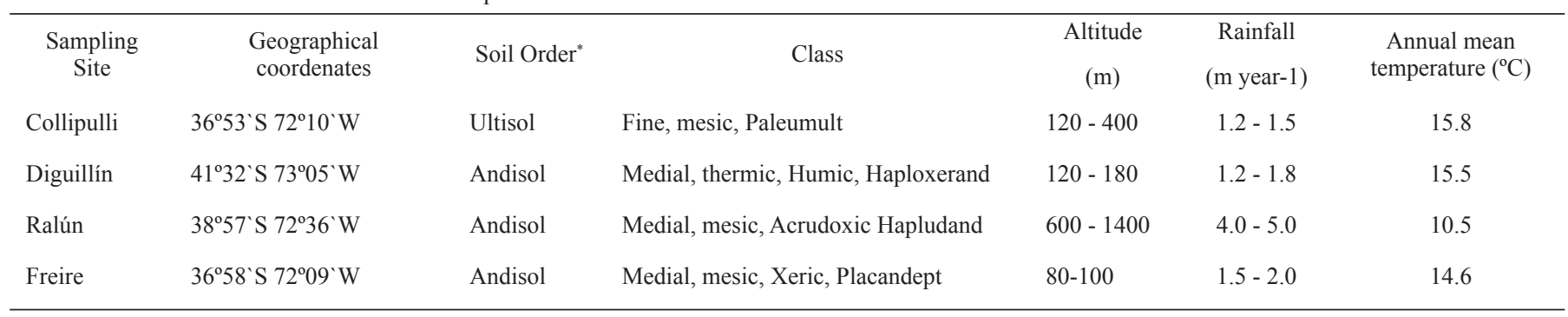

*According to the United States Soil Taxonomy system ${ }^{22}$. 


\section{Mineralogical Analysis}

The Clay samples, from the Collipulli soil (Ultisol) only, were analyzed by Mössbauer spectroscopy, with data collected at room temperature $(\sim 298 \mathrm{~K})$ and $6 \mathrm{~K}$, in a constant acceleration transmission instrument with a $\sim 30 \mathrm{mCi}{ }^{57} \mathrm{Co} / \mathrm{Rh}$ source. The morphology was observed by SEM. Specific saturation magnetization measurements were performed with a portable soil magnetometer designed by Coey et $\mathrm{al}^{2}{ }^{26}$, for which the direct digital readings of the magnetic moment of soil materials were expressed in $\mu \mathrm{J} \mathrm{T}^{-1}$; the specific saturation magnetization $(\sigma)$ was then calculated in $\mathrm{J} \mathrm{T}^{-1} \mathrm{~kg}^{-1}$ for samples of known mass. In the present work, about $50 \mathrm{mg}$ was used to obtain an averaged value from 20 readings per sample.

\section{Chemical analyses and dissolution methods}

The chemical composition of samples was determined by digesting about $0.1 \mathrm{~g}$ (analytical precision) of the dry sample with $\mathrm{HF}$ and aqua regia (10:1.5) in a microwave furnace at $110^{\circ} \mathrm{C}$ during $30 \mathrm{~min}$. After this procedure, the supernatant was separated by centrifuging at $10000 \mathrm{rpm}$ and analyzed for $\mathrm{Fe}, \mathrm{Al}, \mathrm{Si}$, and $\mathrm{Ti}$ with ICP-OES. The clay fractions of the volcanic soil samples were treated with two different solutions in order to extract the poorly crystallized iron oxides: (i) a single 4-h treatment, in darkness, with oxalic acid-ammonium oxalate (OX) at $\mathrm{pH} 3$, according to Schwertmann ${ }^{7}$ and (ii) a single 16-h treatment, in darkness, with sodium citrate - ascorbic acid (CA), at $\mathrm{pH} 6$, according to Reyes and Torrent ${ }^{19}$, using $0.05 \mathrm{~mol} \mathrm{~L}^{-1}$ ascorbic acid and $0.2 \mathrm{~mol} \mathrm{~L}^{-1}$ sodium citrate solutions.

\section{RESULTS AND DISCUSSION}

The spontaneous magnetization for these samples revealed (Table 2) that the Collipulli (Ultisol) soil sample, which has a relatively higher Fe content (Table 3), is magnetic (soil: $\sigma=2.4 \mathrm{~J} \mathrm{~T}^{-1} \mathrm{~kg}^{-1}$; clay: $\sigma=1.2 \mathrm{~J} \mathrm{~T}^{-1} \mathrm{~kg}^{-1}$ ). This feature was also confirmed by the relatively strong attraction of the soil mass to a hand magnet. It also has relatively high clay content $(52 \mathrm{mass} \%)^{20}$; the mineralogy of which is dominated by halloysite and kaolinite aluminosilicates ${ }^{15,21}$.

Table 2. Values of spontaneous magnetization for samples.

\begin{tabular}{lcccc}
\hline \multirow{2}{*}{ Sample } & Soil & Sand & Silt & Clay \\
\cline { 2 - 5 } & \multicolumn{3}{c}{$\mathrm{J} \mathrm{T}^{-1} \mathrm{~kg}^{-1}$} \\
\hline Collipulli* & 2.40 & 1.70 & 1.26 & 1.20 \\
Diguillín & 0.61 & 1.31 & 0.28 & 0.17 \\
Ralún & 0.46 & 0.79 & 0.21 & 0.17 \\
Freire & 0.45 & $\mathrm{Nd}$ & 0.35 & 0.20 \\
\hline
\end{tabular}

"Magnetization data for the Collipulli samples from $\operatorname{ref}^{20}$.

$\mathrm{Nd}=$ Not determined.

Table 3. Chemical composition of the clay fractions for soil samples before (Untreated) and after sodium citrate-ascorbic acid (CA) and oxalic acid - ammonium oxalate $(\mathrm{OX})$ treatments.

\begin{tabular}{lccc}
\hline \multicolumn{1}{c}{ Sampling site } & $\mathrm{Fe}(\mathrm{wt} \%)$ & $\mathrm{Al}(\mathrm{wt} \%)$ & $\mathrm{Si}(\mathrm{wt} \%)$ \\
\hline Untreated & & & \\
Collipulli & 5.6 & 4.2 & 13.6 \\
Diguillín & 3.9 & 8.6 & 10.2 \\
Ralún & 3.8 & 9.9 & 8.4 \\
Freire & 4.2 & 9.3 & 9.4 \\
CA & & & \\
Collipulli & 1.89 & 1.54 & 1.07 \\
Diguillín & 0.97 & 1.50 & 0.36 \\
Ralún & $\mathrm{Nd}$ & $\mathrm{Nd}$ & $\mathrm{Nd}$ \\
Freire & 2.39 & 1.86 & 0.50 \\
& & & \\
OX & & & \\
Collipulli & 0.7 & 0.4 & 0.1 \\
Diguillín & 3.93 & 6.95 & 3.04 \\
Ralún & $\mathrm{Nd}$ & $\mathrm{Nd}$ & $\mathrm{Nd}$ \\
Freire & 4.06 & 7.90 & 3.62 \\
\hline
\end{tabular}

$\mathrm{Nd}=$ not determined.
At room temperature Mössbauer spectra (Figure 1) for the clay fraction of the Collipulli soil (Ultisol) are rather complex, as is usually found for most soil clay materials, and generally consist of an intense central doublet, typically due to superparamagnetic iron (oxyhydr)oxides in very small particles and/or paramagnetic species such as structural iron in the phyllosilicates, along with a variable but usually incipient sextet contribution from magnetically ordered iron (oxyhydr)oxides.

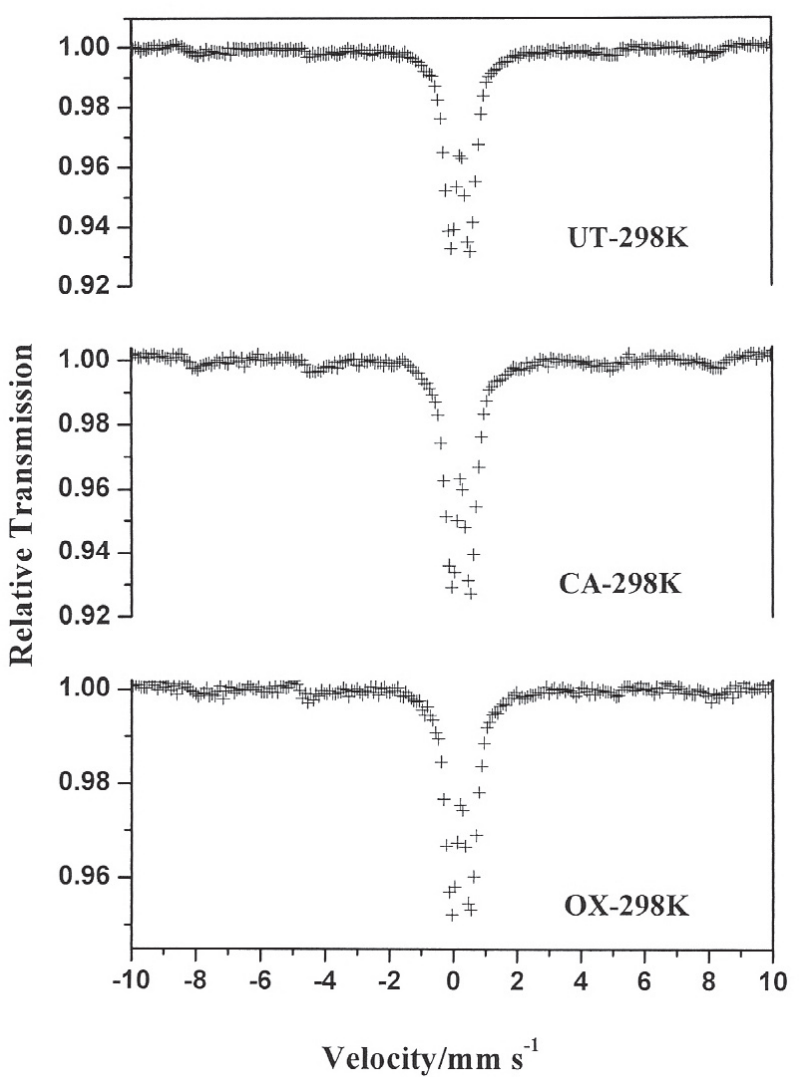

Figure 1.- Room-temperature Mössbauer spectra for the Collipulli clay fraction, before (Untreated) and after CA- and OX- treatments.

The 6-K Mössbauer patterns (Figure 2), even though still complex with multiple subspectra, allow a better interpretation than the room-termperature spectra because most of the superparamagnetic relaxation effects are suppressed. The numerical curve-fitting method identified spectral contributions from magnetically ordered phases and involved two main steps: (i) a modelindependent approach which calculated a hyperfine field distribution, then (ii) on the basis of this information, the hyperfine parameters were estimated by considering the most probable magnetic fields, as indicated by the distribution probability profile, and fitting them with the theoretical Lorentzian-shaped resonance lines. Corresponding hyperfine parameters are presented in Table 4. 

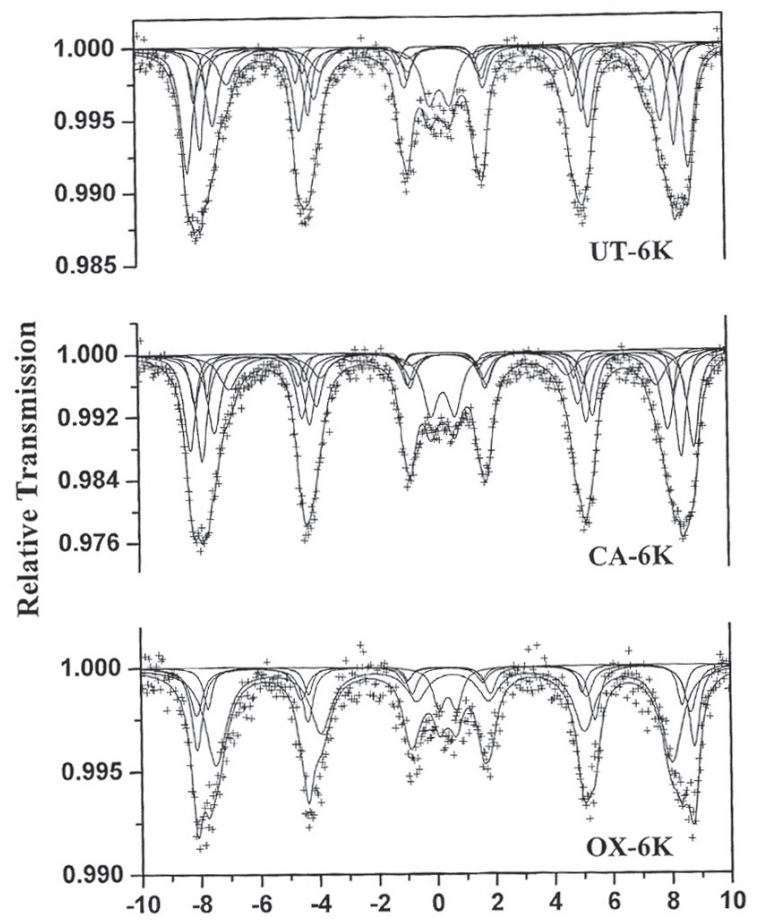

Velocity/mm s $\mathrm{m}^{-1}$

Figure 2.- $6 \mathrm{~K}$ Mössbauer spectra for the Collipulli clay fraction, before (Untreated) and after CA- and OX- treatments.

The Mössbauer hyperfine parameters are consistent with goethite, maghemite, and hematite iron oxides, along with some poorly crystalline ironbearing compounds, which may likely be of the oxyhydroxide group. The lower hyperfine fields observed in spectra of the untreated and CA-treated samples nearly disappear for the OX-treated sample. The relative area of hematite tends to decrease slightly but significantly, from $38 \%$ (untreated) to $21 \%$, with CA, but decreased only to $32 \%$ with OX treatment. Corresponding data for maghemite indicate that the OX treatment promotes a substantial increase in its relative amount, if the higher hyperfine field of 52.0 tesla can be safely interpreted as being due to $\mathrm{Fe}^{3+}$ in octahedral sites of the spinel structure. This interpretation, however, must be taken with some caution because numerical spectral resolution fails to produce a rigorously unique solution for such complex spectra.

The Andisols are darker and have lower iron contents than the Ultisol (Table 3). Organic matter content (expressed by the organic carbon) in the clay fractons ranges from 4.8 mass $\%$ to 11.5 mass \% in the Andisols, whereas it is $1.2 \mathrm{mass} \%$ in the Ultisol.

Andisols are relatively less developed soils than Ultisols, with higher proportions of poorly crystalline iron (oxyhydr)oxides and lower magnetic saturation measurements (for the present soil samples, $\sigma<1 \mathrm{~J} \mathrm{~T}^{-1} \mathrm{~kg}^{-1}$; Table 2 ). Reported mineralogical compositions $s^{12,15}$ of these Andisols (Diguillín, Ralún and Freire) include allophone ( $>50$ mass $\%)$; crystalline species such as halloysite, chlorite, gibbsite, and plagioclase account for not more than 1 - 5 mass \%. Organo-allophanic material was assumed to be at about 1-5 mass $\%$ in the Freire and $<1$ mass\% in the Diguillín soils. All these data agree with the most expected general characteristics for volcanic Ultisols and Andisols ${ }^{15,21}$.

As far as the effects of these selective chemical treatments are concerned, the iron extracted with the OX treatment markedly exceeded that obtained with CA for the Andisol clay samples; but, for the Ultisol, the CA treatment was by far the most efficient to dissolving iron.

Similarly, Si and Al contents extracted with the OX treatment from the Andisol materials were much higher than that of the corresponding extraction with CA (Table 3). Si contents extracted with OX (Si-OX) have been used by some authors to estimate the proportion of para-allophane, allophone, and imogolite (X) contents of Andisols, according to the following expression ${ }^{14,27}$ :
Table 4. $6 \mathrm{~K}$ - Mössbauer parameters for the untreated, and CA (sodium citrate - ascorbic acid) - and OX (oxalic acid - ammonium oxlate) - treated for the Collipulli clay samples. $\delta=$ isomer shift relative to $\alpha \mathrm{Fe} ; \varepsilon=$ quadrupole shift; $\mathrm{B}_{\mathrm{hf}}=$ hyperfine field; $\mathrm{RA}=$ relative area of the subspectrum. $\mathrm{Fe}(\mathrm{III})=$ any subspectrum due to (super)paramagnetic $\mathrm{Fe}^{3+} ; \mathrm{Gt}=$ goethite; $\mathrm{Hm}=$ hematite; $\mathrm{Mh}=$ maghemite and "Lower Field" = any not-assigned subspectrum, for which the hyperfine field value is lower than those of the previous magnetically ordered phases. [ ] and \{ $\}$ stand, respectively, for iron in tetrahedral and octahedral sites of maghemite. Numbers in parentheses refer to errors over the last significant digit, estimated by the standard deviations of the corresponding parameters given by the least-square procedure.

\begin{tabular}{|l|l|l|l|l|l|}
\hline Sample & Subespectrum & $\begin{array}{c}\delta / \mathrm{mm} \mathrm{s}^{-} \\
1\end{array}$ & $\begin{array}{c}\Delta, \varepsilon / \\
\mathrm{mm} \mathrm{s}^{-1}\end{array}$ & $\mathrm{~B}_{\mathrm{h} 1} / \mathrm{T}$ & \multicolumn{1}{|c|}{$\mathrm{RA} / \%$} \\
\hline Untreated & $\mathrm{Fe}(\mathrm{III})$ & $0.45(2)$ & $0.70(2)$ & & $11.2(4)$ \\
\hline & $\mathrm{Gt}$ & $0.51(1)$ & $-0.26(2)$ & $50.0(1)$ & $18(4)$ \\
\hline & $\mathrm{Hm}$ & $0.50(1)$ & $-0.20(1)$ & $52.8(1)$ & $28(3)$ \\
\hline & {$[\mathrm{Mh}]$} & $0.37(1)$ & $-0.03(3)$ & $48.7(1)$ & $5(1)$ \\
\hline & $\{\mathrm{Mh}\}$ & $0.38(1)$ & $-0.03(2)$ & $51.3(1)$ & $8(2)$ \\
\hline & Lower Field & $0.44(2)$ & $-0.16(4)$ & $44.2(1)$ & $12(3)$ \\
\hline & Lower Field & $0.49(1)$ & $-0.23(2)$ & $47.3(1)$ & $19(4)$ \\
\hline & & & & & \\
\hline & Fe(III) & $0.44(1)$ & $0.82(2)$ & & $11.8(4)$ \\
\hline & $\mathrm{Gt}$ & $0.52(1)$ & $-0.21(2)$ & $50.5(1)$ & $22(4)$ \\
\hline & $\mathrm{Hm}$ & $0.52(1)$ & $-0.17(2)$ & $53.1(1)$ & $21(3)$ \\
\hline & {$[\mathrm{Mh}]$} & $0.37(1)$ & $-0.05(2)$ & $49.1(1)$ & $5(1)$ \\
\hline & $\{\mathrm{Mh}\}$ & $0.39(1)$ & $-0.02(3)$ & $51.9(1)$ & $8(2)$ \\
\hline & Lower Field & $0.48(2)$ & $-0.03(4)$ & $45.1(1)$ & $13(3)$ \\
\hline & Lower Field & $0.50(2)$ & $-0.20(2)$ & $47.8(1)$ & $20(5)$ \\
\hline & & & & & \\
\hline OX & Fe(III) & $0.50(*)$ & $0.60(*)$ & & $10.3(6)$ \\
\hline & Gt & $0.52(2)$ & $-0.28(*)$ & $48.1(2)$ & $30(4)$ \\
\hline & Hm & $0.53(2)$ & $-0.18(*)$ & $52.3(1)$ & $32(3)$ \\
\hline & {$[\mathrm{Mh}]$} & $0.43(3)$ & $-0.0(*)$ & $49(1)$ & $11(2)$ \\
\hline & $\{\mathrm{Mh}\}$ & $0.38(1)$ & $-0.0(*)$ & $52.0(2)$ & $18(2)$ \\
\hline & & & & &
\end{tabular}

*Fixed value during least-squares fitting convergence

\section{$\mathrm{X}=[\mathrm{Si}-\mathrm{OX} * 2.8 / 14] * 100$}

The non-crystalline and para-crystalline phases (para-allophane, allophane and imogolite) content (X), so estimated from the Si value from Table 3, is 2 mass \% for the Collipulli clay fraction; for Andisol it is in excess of 50 mass $\%$, as expected ${ }^{12}$

Reyes and Torrent ${ }^{19}$ found differences between the OX and CA chemical treatments on Spodosol and Andisol samples, for which molar ratios of Si and $\mathrm{Al}$ were consistent with those expected for allophane. Different from CA, the OX treatment tends to dissolve preferentially allophane and imogolite.

Typical morphologies of the particles can be inferred by examining the SEM images of the clay samples (Figure 3). From these, both OX and CA treatments have roughly the same effect but CA is more efficient in preferentially dissolving finer particles. Grains from the sample treated with CA had sharper edges than those treated with OX. This may indicate CA tends to dissolve more fine particles from the surface of grain aggregates. Mössbauer spectra at $6 \mathrm{~K}$ (Table 4 and Figure 2) revealed that the relative area of the hematite subspectrum for the CA-treated Ultisol clay sample was about $30 \%$ lower than that after OX treatment. 


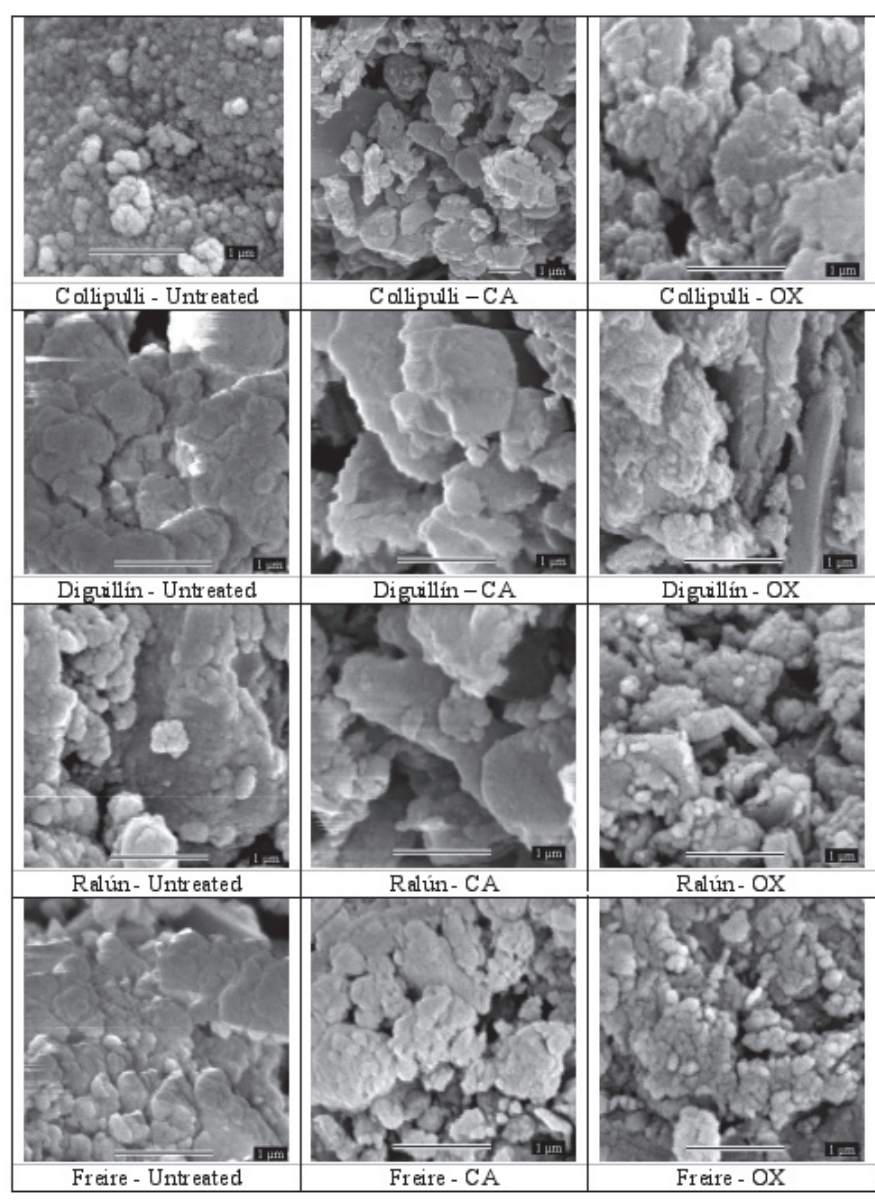

Figure 3.- Scanning Electron Microscopy for clay fractions of Collipulli (Utisol) and Diguillín (Andisol), Ralún (Andisol) and Freire (Andisol) soil samples, before (Untreated) and after treatments with oxalic acid - ammonium oxalate $(\mathrm{OX})$ and sodium citrate - ascorbic acid (CA)

\section{CONCLUSIONS}

Because of their distinct mineralogical compositions, clay fractions from the investigated Ultisol and Andisols respond differently to selective dissolution treatments using oxalic acid - ammonium oxalate at $\mathrm{pH} 3(\mathrm{OX})$ or sodium citrate - ascorbic acid at $\mathrm{pH} 6(\mathrm{CA})$.

Chemical data revealed and electron microscopy images for clay fractions appear to confirm that CA is more effective in removing iron from Ultisol and $\mathrm{OX}$ is more efficient with Andisols.

${ }^{57} \mathrm{Fe}$ Mössbauer measurements at $6 \mathrm{~K}$ indicated that $\mathrm{OX}$ tends to preferentially remove magnetically ordered species with low hyperfine fields; CA has no clear effect on removing those or the identified iron oxides in these volcanic soil materials.

\section{ACKNOWLEDGMENTS}

Work supported by FONDECYT (Chile; grant 1040272), DICYT-USACH (Chile; grant 2070726), MIDEPLAN (Chile; grant Presidente de la República), Prosul-CNPq (Brazil; grant 490132/2006-5), Fulbright (USA)/CAPES(Brazil), and the ERSP program (U.S. DOE/BER, grant DE-FG02-7ER64374, NSF grant EAR 01-26308)

\section{REFERENCES}

1. R.M. Cornell and U. Schwertmann. The iron oxides. Weinheim, 1996

2. K. Norrish and R.M. Taylor. J. Soil Sci. 12, 294, (1961)

3. N. Kämpf and U. Schwertmann. Clays and Clay Miner. 30, 401, (1982)

4. M. A. Blesa, H. A. Marinovich, E. C. Baumgartner and A. J. G. Maroto. Inorg. Chem. 26, 3713, (1987)

5. Arshad, M. A., St. Arnaud, R. J., and Huang, P. M. Can. J. Soil Sci. 52, 19, (1972)

6. J. A. McKeague and J. H. Day. Can. J. Soil Sci. 46, 13, (1966)

7. U. Schwertmann. Z. Pflanzenernähr Düngung Bodenk. 105, 194, (1964)

8. U. Schwertmann. Can. J. Soil Sci. 53, 244, (1973)

9. H. P. Blume and U. Schwertmann. Soil Sci. Soc. Amer. Proc. 33, 438, (1969)

10. O. P. Mehra and M. L. Jackson. Proc. 7th Nat. (U.S.) Conf. Clays and Clay Miner. Pergamon Press London, 1960; pp. 317-327.

11. M. J. Singer, L. H. Bowen, K. L. Verosub, P. Fine and J. Tenpas. Clays and Clay Miner 43, 1, (1995)

12. E. Besoaín. Suelos Volcánicos de Chile. J. Tosso Editorial. INIA, Santiago, Chile, 1985

13. G. Galindo, E. Barros and M. Escudey. Ciencia e Investigación Agraria 13-2, 64, (1986)

14. A. Sadzawka and L. Porte. Agricultura Tecnica. 45-4, 329, (1985)

15. C. Pizarro. Mineralogía de los Óxidos de Hierro y Equilibrios de Intercambio Catiónico en Suelos Volcánicos Chilenos. DSc Thesis in Chemistry, Universidad de Santiago de Chile (2001) 115 p (in Spanish).

16. C. Pizarro, M. Escudey, J. D. Fabris, and A. B. Almeida. Commun. Soil Sci. Plant Anal., 31 (19\&20), 3113, (2000)

17. C. Pizarro, N.R. Furet, R. Venegas, J. D. Fabris and M. Escudey. Bol. Soc. Chil. Quim. 45, 243, (2000)

18. C. Pizarro, M. Escudey, J. D. Fabris and A. B Almeida. Commun. Soil Sci. Plant Anal. 32 (17\&18), 2741, (2001)

19. I. Reyes and J. Torrent. Soil Sc. Soc. Am. J. 61 (6), 1647, (1997)

20. C. Pizarro, J. D. Fabris, J. Stucki, V. K. Garg, C. Morales, S. Aravena, J. L. Gautier and G. Galindo. Hyp Int. 175, p. 95-101 (2007)

21. M. Escudey, G. Galindo, J. E. Förster, M. Briceño, P. Díaz and A. Chang. Commun. Soil Sci. Plant Anal. 32 (5-6), 601, (2001)

22. US Soil Taxonomy, A Basic System of Soil Classification for Making and Interpreting Soil Surveys is available in PDF format, for printing or viewing, at http://soils.usda.gov/technical/classification/taxonomy/

23. D. K. Cassel and D. R. Nielsen. Field capacity and available water capacity. In: A. Klute (ed). Methods of soil analysis. Part 1. Physical and mineralogical methods. $2^{\text {nd }}$ ed. American Society of Agronomy and Soil Science Society of America, Madison, Wisconsin, USA, 1986, pp 901926.

24. G. W. Gee and J. W. Bauder. Particle-Size Analyisis. In: A. Klute (ed). Methods of Soil Analysis. Part 1. Physical and Mineralogical Methods. $2^{\text {nd }}$ ed. American Society of Agronomy and Soil Science Society of America, Madison, Wisconsin, USA. 1986; pp 383-411.

25. M. L. Jackson. Soil Chemical Analysis. Advanced Course. Revision of $2^{\text {nd }}$ edition, $11^{\text {th }}$ printing, 1985. Paralled Press University of WisconsinMadison Libraries, Madison, Wisconsin, USA, 2005.

26. J. M. D. Coey, O. Cugat, J. McCauley and J. D. Fabris. Revista de Física Aplicada e Instrumentação, 7(1), 25-30, (1992)

27. R. L. Parfitt. Soil Taxonomy News, 5 11, (1983). 